DOI: https://doi.org/10.30525/978-9934-26-108-4-9

Vladimir Shedyakov

Doctor of Sociological Sciences, Candidate of Economic Sciences, Associate Professor, Free-lance

\title{
THE STATE IN THE SYSTEM OF PROTECTING NATIONAL INTERESTS
}

\section{Summary}

Optimizing transformations during the transition period requires the use of the entire multilateral system of mechanisms to protect national interests. The state occupies an essential place, in particular, the establishment of forms of public-private partnership in coordinating diverse initiatives and creative searches. At the same time, on the one hand, the independence and security of development force them to predominantly rely on their own forces. On the other hand, the refusal to unify the social structure (in particular, statehood) makes it easier to increase efficiency, flexibility and adaptability while maintaining loyalty to national foundations and traditions. The two most noticeable trends in the transformation of the state structure are the strengthening of totalitarian-corporate characteristics or features of democracy. Accordingly, the depersonalization of responsibility - or its embodiment in specific leaders is realizing. At the same time, as you know, selection and promotion in the corporate sector has nothing to do with democracy. And the processes of pathologizing political and economic life may imply a departure from general, direct, secret and equal elections to senior government positions, and include broad manipulative capabilities of the media sphere. 


\section{Введение}

Как известно, государство всё активнее действует в экономической сфере, «погружаясь из надстройки в базис». Сформировались тенденции усиления воздействия на некоторые государства, с одной стороны, коммерческого сектора, с другой - качеств лидеров и институтов. Между тем кризисы последних лет демонстрируют: во-первых, именно государства (а не, например, транснациональные компании или неприбыльные организации) пытаются отражать вызовы, возникающие перед человечеством; во-вторых, сформированная за последние четверть века общественная система на уровне как социально-политического строя, так и международного порядка стала критично слабой в решении жизненно важных проблем; в-третьих, важнейшие социальные гарантии (8-часовой рабочий день, декретный оплачиваемый отпуск, больничный лист, бесплатное и качественное жилье, здравоохранение, образование, досуговые организационные формы и т. д.), данные ойкумене лагерем реального социализма с его деструкцией, подвергаются активным попыткам демонтажа, а интересы народных масс подменяются узкоэгоистичной заинтересованностью наднационального олигархата. Государственный образ мышления базируется на умении заблаговременно создавать подсистемы, повышающие шансы использовать благоприятные возможности и минимизировать угрозы для общества; тем самым ответственность государства перед народом требует способности предвосхищать изменения и бедствия. Между тем курс на приращение общественного богатства прямо требует и максимизации доступа к возможностям развития и реализации в просоциальном творчестве высокоиндивидуализированного комплекса одарённости каждого, и усиления роли государства во время парадигмальных трансформаций [1-5].

После включения мировой системой империализма в себя существенной части стран реального социализма во многом был исчерпан потенциал распространения посткапиталистической модели организации общественной жизни, нуждающейся не только во внутренней, но и во внешней эксплуатации (в частности, за счёт монопольно неэквивалентного обмена). Тем самым смена общественной парадигмы стала драматически необходимой. Укрупнённо конкурируют два пути восстановления регулируемости основных процессов целостности: через кастовое или же социализированное устройство общества, каждый из которых связан со своим представлением о нормативном, справедливом и желательном в образе жизни, направлениях индивидуального и общественного изменения, структуре производства, распределения, обмена и потребления. С одной стороны, весомыми факторами в складывании конечного вектора выступают трансформации государства и воспитания человека. С другой нарастание массовых протестных движений («жёлтые жилеты», Осcupу 
Wall Street, ANTIFA, Black Lives Matter) и формирование альтернативных структур власти и управления явно показывают общественное недовольство характером структур и институтов.

Проблемы соотношения идеала и реалий государства, его и граждан взаимной ответственности друг перед другом закономерно волновали еще Конфуция и Платона. В работе учтены дискуссии и прогнозы Брукингского института (Brookings Institution), Изборского клуба, Международного дискуссионного клуба «Валдай», Клуба экспериментальной истории, Международного форума «Евразийский образовательный диалог», Петербургского международного экономического форума, Ярославского инвестиционного форума, корпорации «Рэнд» (RAND Corporation, Research and Development), Стрэтфора (Stratfor, Strategic Forecasting Inc.), Фонда «Наследие» (Heritage Foundation), Центра стратегических и международных исследований (CSIS, The Center for Strategic and International Studies), Примаковских чтений, Римского клуба и Зальцбургского семинара. Так, теоретико-методологические ресурсы анализа были развиты при учёте подходов и мнений относительно развития взаимосвязей общества, государства и человека Р. Акоффа, Ж. Алфёрова, В. Арнольда, Ж. Аттали, А. Ачлея, И. Ашманова, Д. Баймана, М. Бакунина, Р. Басса, У. Бека, Г. Бехманна, Л. Берталанфи, Ф. Броделя, Д. Брэдфорта, А. Бузгалина, П. Бьюкенена, С. Бэннона, В. Вазюлина, И. Валлерстайна, А. Вандама (Едрихина), А. Вольского, Д. Вудворда, Э. Вульфа, Р. Газенко, А. Галушки, В. Гееца, Р. Гейтса, Б. Гидаспова, Э. Гидденса, А. Горца, С. Глазьева, В. Глушкова, А. Громыко, Б. Гросса, Т. Грэма, Дж. Гэлбрейта, Э. Гэмбла, М. Делягина, А. Джонса, И. Джохадзе, В. Дрожжинова, А. Дынкина, В. Ефимова, Ю. Жукова, Д. Зеркалова, А. Зиновьева, И. Ильина, В. Иноземцева, Д. Калаича, М. Калашникова, Л. Канторовича, Р. Канунго, С. Караганова, С. Кара-Мурзы, M. Кастельса, В. Катасонова, М. Келдыша, Дж. Кеннана, Г. Киссинджера, М. Ковальчука, А. Колганова, Дж. Конгера, В. Корнилова, М. Корнфорта, И. Коротченко, С. Кортунова, С. Кравченко, Р. Кравчика, А. Кули, Д. Куликова, Т. Куна, Т. Купманса, С. Кургиняна, Е. Лариной, Дж. Лафлэнда, А. Лаффера, П. Лебедева, М. Леонтьева, Э. Либановой, В. Малахова, Г. Малинецкого, А. Мартынова, О. Матвейчева, А. Медведева, С. Милза, Г. Моргентау, Н. Нарочницкой, Д. Нексона, Р. Нисбета, Дж. Ноэля, В. Овчинского, Э. Ожиганова, И. Острецова, С. Переслегина, Д. Перкинса, Ю. Петрова, А. Печчеи, В. Полеванова, Е. Пономарёвой, В. Правдивцева, А. Пыжикова, Т. Пфеннинга, В. Пякина, Э. Розенталя, Б. Рассела, В. Сагатовского, Л. Савина, Т. Сакайи, Б. Сандерса, А. Святогора, Т. Сергейцева, К. Сивкова, Б. Славина, Ю. Соколова, Г. Спенсера, Е. Спицына, В. Суслова, Н. Старикова, Н. Талеба, Н. Тичи, Д. Томпсона, В. Третьякова, Н. Трубникова, С. Уралова, Р. Черена, Н. и П. Фё- 
доровых, В. Федотовой, Р. Фишера, Дж. Фулбрайта, А. Фурсова, М. Хазина, А. Харина, Р. Хауса, С. Хелемендика, О. Четвериковой, И. Шишкина, И. Шнуренко.

Основной целью исследования при подытоживании материала выступает содержательная характеристика диалектики государства и общества, места личностей и институтов в интеграции интересов и создании условий развития и проявления творческой активности масс. Для этого интегрированы исторический и логический методы исследования и изложения, анализ, синтез и сравнение.

\section{Раздел 1. Защита государством национальных интересов и фиксация взаимодействия интересов}

Государство как орган защиты национальных интересов выступает фокусом их интеграции и фиксации направленности динамики. Как известно, в мире сосуществуют сонмы цивилизаций, социокультурных стилистик, сведённых в культурные миры. Судьбы их определяются силой исходных импульсов, геополитическими обстоятельствами (внешним вызовом, наличием союзников, др.), качеством управления. Соответственно, колебания в мягкой социальной системе имеют амплитуду меньше, а частоту выше, нежели в жёсткой. Объединительное начало при этом находится либо внутри, либо вовне самого этноса, его государства. Сверхпроект - форма не только структурирования безопасности и развития экономики и общества, но и интеграции (в частности, гармонии интересов), порождающей чувство сопричасности с историческими свершениями народа. И если миссия и ответственность элиты - в отражении национальных интересов и воли народа, то в зоне ответственности самого народа - несение своих представлений о справедливом, нравственном, нормативном, путём чего и становится творчество как восхождение к лучшему (Истине, Добру и Красоте). А механизмы государственно-частного партнёрства предоставляют обширные возможности для интеграции разнородных интересов (прежде всего, публичных и приватных) [6-11].

Между тем ныне культурная и историческая разнородность мира возросла, влияя и на формы своего нормативно-юридического закрепления. Как известно, весомой частью практико-теоретического освоения мира становится понимание прав и обязанностей. Закрепление их соотношения, признаваемого народом в качестве справедливого, позволяет усилить и его характер как субъекта исторического творчества (а следовательно, вклад в материальную и духовную культуру и достижения ойкумены как целого), и устойчивость к враждебным воздействиям. Между тем человечество фиксирует свои представления о должном в системе регламентаций, включающих нормы нравственные и юридические, где присутствуют начала кросс-культурные и специфические для данного культурно-цивилизационного образования. 
Другими словами, как формально-юридическое, так и социокультурное унормирование общественной жизни принимает многообразие черт, свойственное конкретному культурно-цивилизационному миру, и накрепко впаяно в систему защиты своего суверенитета (политического, экономического, информационного и т. д.).

Для государства важно обеспечить защиту культурных кодов, но не сеять рознь среди населения. Структурирование социальноэкономическим началом всё заметнее дополняется этнокультурным. А это значит, что социальная система обретает качества несистемной социальной общности. Если первая стремится к целостности, то вторая её лишена, оставаясь конгломератной, мозаичной. Первая предполагает неравенство частей и строгую иерархию организаций, вторая равноположенность, самоценность и гармонию элементов, отсутствие заранее установленного масштаба и норматива. В первой человек предстает прежде всего как личность, во второй - как индивидуальность. Но если свою классовую принадлежность и экономическое положение каждый может при желании изменить, то этнокультурная определенность и духовно-психологическая составляющая оказываются непреложной данностью. В результате сами социальные образования становятся особыми типами объектов, создаваемыми не атомами-ингредиентами, а связями, которые имеют вероятностный, стохастический характер. Их детерминация зачастую не причинна, а синхронна. С усилением же этнокультурных и духовнопсихологических начал это положение приобретает всё большее значение. Попытка же переноса удобных формул представления сознанием социальной реальности заведомо обедняет представления о мире, упрощает его картину и абстрагирует от существенных моментов. Причём под доминантой атрибутов социальной системы сохраняются очевидное социальное неравенство и четкость иерархии связей «центр полупериферия - периферия» (хотя и здесь они утрачивают полярность и экономизм). Центр оформляется в несколько «зон прорыва», а периферия (в т. ч. внутри самого «ядра») характеризуется не столько производством уходящих форм общественной организации, сколько маргинализованными массами. Налицо отношения «центра» и «периферии», но нет в явном виде их самих как специфических структурных уровней. Фрагменты же, инициируемые доминантой атрибутов несистемной социальной общности, не несут признаков неравенства и иерархий, однако включают институционализацию по признаку типичности и традиций. Здесь равнозначны, самоценны и рядоположены разные регионы, например западно-христианский, восточно-христианский, исламский, индо-буддийский, конфуцианскобуддийский. Диалогизм каждой из пар различен и задается в первую очередь этнокультурными параметрами. Часть из них подвижна. Государства неравномерно охвачены их пространством, кое-где их 
признаки налагаются друг на друга и сталкиваются. Появляются новые признаки. Происходит возникновение синтетических либо синкретных форм с особыми свойствами. В результате на передний план выступают процессы циклические, в основании которых - сочетание архаического уровня (фольклор, язык, этноосмысление, религиозные отличия) с «осевым» (понимание великого священнокнижия и отнесение себя к одному из культурных миров) и постглобальным. Между тем ныне ядро общественного богатства складывается вокруг творческого потенциала общества, а на передний план выходит состязание культурноцивилизационных миров в доступе к ресурсам жизнеобеспечения развития и технологиям их использования в экономике, включая контроль над миграцией экономически активного населения, над качеством и доступностью образования, над трансфертом инноваций и проч.

Уже очевидно: богатство и мощь стран Запада - следствие отнюдь не качества социальной организации или же государственного устройства, a лишь веков ограбления остального мира в военных, торговых, финансово-спекулятивных авантюрах. Видимость изобилия для платежеспособных избранников (при нарастании абсолютного и относительного обнищания масс населения, безработице и обессмысливании жизни) скрывает действительность, а обилие форм манипулирования и пропаганды - глубинную сущность происходящего там. Разобщённость (от классических «двух наций» до полной, трансцендентной взаимной отчуждённости) делает случайной цельность и органичность личности. Собственно, как известно, восстановлению целостности личности, защите прав и свобод человека (не только у себя, но и во всем мире) и был в числе прочего подчинен коммунистический Проект. Страны империализма были вынуждены в ответ тратиться на свою имиджевую привлекательность - с известным смещением акцентов в сторону патологизации общественной жизни. Это естественно: бум превращенно-иррациональных форм - одно из следствий перезревшего характера капиталистических отношений, в свою очередь, включающееся в перестраивание всего структурирования жизнедеятельности на началах обесценения человека ради накопительства/прибыли и наслаждений/консьюмеризма. Отвлечение на ложные социальные явления и идеологические фикции упрощается тотальностью пропагандистской машины Запада после торжества там информационной попсы и радикальным опрощением общественной и индивидуальной жизни, ускорившем пауперизацию основной части населения, бюргеризацию интересов, деградацию элит и милитаризацию политики (в т. ч. ресурсами торговых и информационных войн со всем светом).

Противоположный задумываемому результат действий - одна из ярких примет системного характера кризиса. Сам системный мировой экономический кризис начала XXI столетия - проявление общего кризиса доминантной формы индустриализма, однако её преодоление 
требует учёта постиндустриальных перспектив экономики знания, а также диапазона её возможностей. Таким образом, ныне кризисность характеризует само состояние общественной (в Т. ч. политикоэкономической и финансово-спекулятивной) системы ойкумены. В частности, недостаточно рационально расходуются и человеческий потенциал, и природные ископаемые, и технико-технологические возможности. Усиливает давление на общую ситуацию незанятый (или занятый неэффективно) трудовой потенциал. Одновременно накапливаются и риски от промедления в проведении назревших реформ в организации и регулировании экономической жизни ойкумены. В то же время востребованный омертвившимся обществом Запада социальный каннибализм получил логичное дополнение в виде кастовости, где париям противостоит номенклатура, в которую выродились через механизмы личной унии и взаимопроникновение пласты элит и истэблишмента. На данный момент (что многоуровнево проявляется массовыми протестными движениями, нарастающим научно-техническим и социально-экономическим отставанием, лихорадкой милитаризма, санкционными и информационнопропагандистскими кампаниями и проч.) в своей деградации Запад прошёл точку невозврата. Его население отчаянно мечется, пытаясь преодолеть законсервировавшиеся устои. Причём формируется не двоевластие, а многовластие, где перемежаются представители народа и самозванцы, революционеры и провокаторы, стихийные лидеры и «подсадные утки» западных спецслужб. Потоки голословных заявлений и целенаправленных фейков официальных лиц и политиканов Запада давно вынесли их за пределы полномочий действительных представителей народов. США опять свёртываются в помесь изоляции и агрессии, Европа осознаёт себя «маленьким полуостровом в великой Азии». Но это - закономерность проявления неравномерности исторического развития. А вот случайность - наложение этого обстоятельства на переход к новой общественной парадигме в условиях катастрофического угасания прежнего созидательного импульса Запада. А уж события так называемого «разноцветного бархата» конца XX начала XXI веков зачастую и вовсе не соответствуют классическим определениям революций. А жестокие расправы и массовые избиения «жёлтых жилетов», силовые подавления многотысячных демонстраций в Берлине, игнорирование базовых прав и свобод человека при разгоне Occupy Wall Street, «жёлтых жилетов» и прочие подобные вошедшие в правила западного подавления оппонентов преступления лишь провоцируют дальнейшие события. Усиление альтернативных группировок во власти - важное условие её бездействия и паралича силовых структур. Концентрация сил в критически уязвимых местах и неожиданность действий - необходимость захвата власти. Перехват выражения протестных настроений агрессивно-деструктивным 
меньшинством демонстрирует беспомощность социально-политических структур. Правомерно, что шквал протестных движений на Западе ещё раз обратил внимание на то, что крайне неэффективная модель государственного порядка и общественного устройства существует за счёт многовекового обирания остальных народов (часто - с геноцидом коренного населения, уничтожением носителей более гуманных альтернатив).

Удар пандемии еще раз убедительно показал: страны империализма не стремятся и не могут не только поддержать какие-либо другие государства, но и обеспечить социальную (в частности, социальномедицинскую) защищённость собственному населению. Если целью медицинской, образовательной и других подсистем является извлечение прибыли, то жизнь конкретного человека оценивается именно с этих позиций. Более того, ужасающая дифференциация в заболевании и смертности по классовым и даже расовым признакам проявила рост реальной сегрегации в организованном по капиталистическим лекалам обществе. Опять-таки, при высасывании соков из всей ойкумены (а когда пришла эпидемия, это коснулось и перетаскивания к себе врачей, средств индивидуальной защиты, лекарств и т. д. отовсюду и любыми путями) страны Запада проявляли крайне противоречивый курс относительно рекомендаций населению, а последнее быстро скатилось к погромам магазинов и т. п. Далеко не случайно именно социалистический Китай сумел как регионально локализовав распространение болезни, эффективно поставить ей преграду, так и протянуть руку помощи другим народам. Среди первых пришедших на помощь и поразивших качеством внутренней мобилизации (а потому и небольшого коэффициента смертности) - исключительно социалистические и прошедшие социалистическую стадию страны (Куба, Китай, Россия, Вьетнам). Соответственно, постройка в кратчайшие сроки без ущерба для качества новых специализированных медицинских комплексов для излечения инфекционных больных, улучшение в кратчайшие сроки социально-эпидемиологической обстановки, высокая эффективность противоэпидемических мер, низкий уровень смертности от коронавируса, максимальное количество проведенных тестов за сутки и мгновенное принятие расширяющегося комплекса мер поддержки граждан - это в очередной раз продемонстрировали отнюдь не страны Запада. Создание новых вакцин, лекарств, производственных и медицинских мощностей опять же было осуществлено не всё более отстающим Западом.

Таким образом, речь идёт отнюдь не о произвольной благотворительности предпринимателей и некоммерческих организаций, а о планомерном изменении всего курса общества. Использование диапазона возможностей сетевизации может стимулировать как нарастание социально-политического хаоса, так и 
укрепление национальных государств, умеющих интегрировать базовые ценностно-смысловые комплексы своих культурно-цивилизационных миров с принципиальными инновациями эпохи. Проявившиеся и находящиеся в анабиозе стратегии могут оказаться лишь отложенной смертью ойкумены, а могут быть чреваты развёртыванием созидательной силы кластеров дальнейшего расцвета. Умение усилить вектор социальной ответственности - это весомый фактор формирования и реализации политико-экономических стратегий. Социально ориентированное государство - рычаг соединения сил общественного саморегулирования с сознательными действиями по коренной модернизации условий деловой активности. Утверждение демократических принципов регулирования жизнеустройства также увеличивает значимость для общества социальной педагогики: массовое развитие сознательной инициативы (прежде всего в труде и управлении) требует адекватных образованности и воспитания. Так, и история преодоления кризисов уже отчётливо продемонстрировала вялый характер социальной помощи со стороны своекорыстных олигархических группировок, и сформировавшиеся глобальные вызовы требуют совершенно иного уровня координации для масштабного политико-экономического маневрирования. Резкое углубление системного кризиса, в глобальном масштабе охватившее политикоэкономическую и культурно-цивилизационную целостность, вывело в ядро главного внутреннего противоречия столкновение интересов компрадорского олигархата (часто - под либерал-националистическими лозунгами) и народов в определении ведущей направленности комплекса вопросов трансформаций государства, науки, промышленности, технологий и коммуникаций, права, образования, социальной сферы, политической идеологии и психологии.

Раздел 2. Эволюция государства.

Социальное государство в переходный период

Неадекватность господствующих моделей новым историческим вызовам требует инновационности решений в вопросах государственного строительства, лишая возможности эффективного заимствования по кардинальным направлениям. Соответственно, каждый культурно-цивилизационный мир нарабатывает свои модели: и трансформирования, и нового состояния - по опыту, условиям, пониманию задач. И подлинная суверенность: политическая, экономическая, идеологическая, духовная неотделима от создания собственной модели будущего. Вместе с тем без реального народовластия нет ни продуктивной защиты коренных национальных интересов, ни максимизации творческой активности.

Способность народа к политико-экономической самоорганизации имеет свойство становиться непременным условием качественной 
реализации прочих направлений его творческой активности. Соответственно, создание и развитие механизмов реализации народного суверенитета относятся к числу приоритетов структурирования общественной организации. Отстаивание своей самобытности - условие не только успеха, но и просто выживания. Напротив, формирование социально-политической культуры инфантилизма и иждивенчества, ожидание «манны небесной» ведёт к угодничеству перед сильными в данный момент и предательству интересов народа. Аппарат власти либо средство насилия и принуждения, либо направление делегирования и наделения полномочиями, создаётся на основании доверия вокруг базовых ценностно-смысловых комплексов или договора. Но вирусность чужеродных подходов в местной форме не только концентрируется в слое компрадорства/коллаборационизма, но и обостряет самозванство (в т. ч. олигархов), непосредственно или в конечном счёте вынужденное акцентировать силовой блок и формировать полицейское государство для паразитирования на народе. Соответственно, кардинально важным в период форсированных преобразований международных отношений становится обстоятельство, кто и в чьих интересах будет осуществлять перемены. В частности, будут ли они происходить в коренных интересах народов мира или же транснациональных корыстно-олигархических кланов. Причём уже ближайшие годы могут стать критичными, решающими в определении архитектоники и вектора трансформаций ойкумены, когда в обострившейся стратегической конкуренции культурно-цивилизационных миров определится «удельный вес» и «место» каждого из них, уровень и образ жизни людей в нём.

И если миссия и ответственность элиты - в отражении национальных интересов и воли народа, то в зоне ответственности самого народа несение своих представлений о справедливом, нравственном, нормативном, путём чего и становится творчество как восхождение к лучшему (Истине, Добру и Красоте). Предоставление для всех равных условий жизнедеятельности - важнейшее направление повышения массива исторического творчества народа. Лидерские группы Запада и Востока выявили свои принципы, приоритеты и ценности, задали грань между миром «горним» и «дольним». Деградирующая часть периферии выступает объектом манипулирования, а не субъектом истории. Разность потенциалов скапливается в полупериферийной зоне и на грани миров. Здесь - возможности неожиданных мутаций. Всеобщность, достигнутая капиталом в эру индустриализма (модернизма), сохранила и ниши воспроизводству на иных началах. Народы, попавшие в «турбулентное завихрение», выделяются не столько уровнем эффективности, сколько экзотикой социальной структуры и политической организации. Но вернуться в исторический поток ранее было легче, чем сойти с него на свою тропу. Другое дело постглобальность с её развитийным плюрализмом и культивируемым 
разнообразием. Совокупная общественная эффективность и хозяйственная конкурентоспособность в постсовременных условиях обеспечиваются развитием и реализацией личности и персонализацией деятельности, а отнюдь не нивелированием людей и усреднением функций. Трансформации способа производства, научно-технической и социально-экономической сторон прогресса человечества привели к кардинальному росту роли человеческого и социального факторов жизни общества. В этих условиях дополнительные вложения «в человека» и «в общество» - это отнюдь не обременительная социальная нагрузка, а непременное условие качественного участия в конкурентной борьбе на верхних этажах экономики, где место экономии на переменном капитале в качестве магистрального направления получения стратегического выигрыша занимает творческая интеллектоемкая деятельность, требующая тщательной подготовки и обеспечения, в том числе путем качественных стимулирования и управления. Более того, попытки поиска обоснования возможного отката в развертывании прав человека и гражданина - кардинальная угроза не только для узкоэкономического, но и для общесоциального развития личности и общества. Уровень реализации прав человека, качество его жизни, возможности творческой самодеятельности и самовыражения принципиальные завоевания социального прогресса, его неотъемлемые черты. Социальность - то, что прямо ориентировано на воспроизводство человека как личности в единстве трех начал биологического (индивид), социально-экономического (собственно личность) и духовнопсихологического (индивидуальность). Невостребованность личности не компенсируется использованием рабочей силы: сам труд является и эффективным способом социализации человека, и методом обмена способностями. Социальные отношения - нечто более сложное, нежели направленное целевоплощение. Их использование часто основывается на интуитивном понимании и игровых (своей и/или чужой игры) взаимодействиях. Так что если физика может стремиться к причинному объяснению, то удел обществоведения - понимание смысла процессов. Этнос зачастую выступает как самостоятельная и недробимая хозяйственная величина с собственной волей, задачами, привычками. Именно сверхиндивидуальные, сверхэгоистические и другие «трансцендентные» факторы часто оказываются решающими на макрои микроуровнях хозяйствования. Это требует от абстрактно-упрощенной схемы «человека экономического» перейти к гораздо более полной концепции «человека творческого», позволяющей изучать общественные отношения на основе социокультурных стилистик, исторической памяти, традиций народа. Налицо воплощенность в системе социальных отношений идеального, сверхиндивидуалистического понимания человека и общества. За иллюзией же верховенства потребительских интересов каждого легко различима 
жестокая и предельно отчуждённая воля «техноструктуры», задающая индивидам их потребительский (редуцируемый до биологии) стереотип. А распад личности и индивидуальности до уровня индивида, доминирование биологического над социальным - это и есть деградация человека и этноса.

Понимание необходимости баланса прав и обязанностей человека и гражданина имеет конкретно-исторический характер, завися как от стадии развития, так и от базовых ценностно-смысловых комплексов культурно-цивилизационных миров. Накопление человечеством технико-технологических и социально-материальных инноваций создаёт предпосылки не только акцентирования духовно-интеллектуальной сферы, но и усиления социальных функций государства. С прохождением волн машинизации, автоматизации, а затем и системной роботизации потребность в энергетической силе человека, его рутинной деятельности падает. Повышение ценности развития и просоциальной реализации творческой одарённости человека (прежде всего в труде и управлении) требует радикального расширения массива творчества, а значит, допуска к возможностям общества максимально большого круга населения. Чтобы быть конкурентоспособным и эффективным, государство обязано акцентировать характеристики социальности.

Ныне социальная защищённость - непременное условие подъёма совокупного общественного богатства в его стратегическом понимании. Вместе с тем если система социалистических стран наращивала усилия по расширению корзины социальных, политических, экономических, экологических и других прав и свобод человека, то период конца XX начало XXI веков был ознаменован попытками переложить тяготы кризиса империализма на плечи широких масс, что дало дополнительный толчок поляризации населения. При этом уже очевидно: тотальная приватизация вовсе не привела к появлению «эффективного собственника». Более того, часто захват ранее общенародного достояния часто приводил к хищнической эксплуатации, появлению монопольной ренты (в частности, от владения природными ископаемыми), резкому нетрудовому расслоению населения, сдаче коренных интересов своего культурно-цивилизационного мира ради снисходительного признания Западом и перевода туда всего дорогого: капиталов, недвижимости, семьи и т. д. Обесценивание достижений (в т. ч. по достоинству вошедших в «золотой фонд» всей ойкумены) собственных стран при угодливом лакействе перед баскаками глобального империализма коррелировало с размыванием реального суверенитета. Попытки равняться на дорогие и неэффективные западные медицинскую, образовательную и другие системы ускоренно разрушали богатое наследие социализма. Естественно, итоги приватизации 90-х и источники быстрого обогащения требуют самого серьёзного расследования и пересмотра; например, богатства недр и созданное 
многими поколениями тружеников должны быть возвращены народу с прибылью от периода их эксплуатации частными лицами. Отстаивание действительного суверенитета предопределяет ориентацию на эндогенный путь развития с акцентированием импортозамещения и подъёма технико-технологических циклов, прежде всего - для удовлетворения как стратегических потребностей, так и новейших промышленных укладов.

Место социальности в развитии постсоветских общественных отношений - особое. Во-первых, общемировая постглобальная общность хозяйства приобретает социальную доминанту развития, когда подходить и к экономике надо непременно с идеологическими, нравственными и геополитическими мерками. Во-вторых, взаимосвязи советского общества имели преимущественно социальную, а не коммерчески-гешефтную природу. В-третьих, с повышением зрелости всякого общества в нём нарастает влияние общесоциальных механизмов культурной регуляции. В-четвертых, радикально меняются стереотипы самого экономического поведения. Наконец, в-пятых, исчезает прежняя «трудовая» этика: если для труда как такового деятельность и отношение взаимодействуют преимущественно внешним образом, то для творчества социальные отношения - смысл и опора деятельности. В результате для анализа общественных трансформаций все большую роль начинают играть отношения хозяйственные, принципиально отличные от производственных. Хозяйственные отношения далеко не системны, более поверхностны, субъективированы, динамичны, подвержены влиянию намного большего числа разнообразных факторов. На смену рыночному романтизму силовых решений Модерна с его ожиданием быстрого линейно простого скачка в общемировую систему связей приходят более реалистические представления, включающие понимание необходимости чередования прорывов и отступлений в трансформации. Ничего ещё не решено. На будущее способны оказать влияние и самые малые толчки в точке бифуркации, расстановка людей, влияния регионов, умение политических сил, осознание специфики новой эпохи. На гребне (гипер)индустриализации особенно шатко равновесие, особенно необходим баланс сил, секторов, укладов - в политике, экономике, социальной сфере и, конечно, государственном строительстве.

С этих позиций трактовка переживаемых событий объективна только с учетом исторической памяти и особенностей социальной культуры этноса. Характер социальных изменений при переходе от одного цикла к другому может существенно разниться. Так отграничиваются вестернизация, форсированное развитие, догоняющая модель и прочие варианты модернизации как движения от общества традиционного к современному, от производства аграрного к индустриальному. В случае перехода к укладам инновационно-синергическим, постинформа- 
ционным речь должна идти уже о постглобальной (гипер)индустриализации. В переходный период крепнет феномен трансформации глубинных, многосторонних преобразований, имеющих своим основанием модернизацию, то есть разрушение традиционного социально-экономического и политического порядка, его замену многопартийной демократией, новым набором агрегирующих и связующих механизмов, открытостью для обмена идеями, технологиями, кадрами с внешним миром, разумной кредитно-денежной стабильностью и становлением гибкого частного сектора для обеспечения приемлемого качества жизни, политической стабильности, экологической безопасности, экономического развития и достойного места в мирохозяйственных связях будущего. При этом нужно различать общие циклы существования цивилизаций от специфических циклов модернизации. Естественно, что нынешняя волна трансформации многое наследует из прежних циклов, но привносит и кое-что своё [12-16]. При всякой модернизации общественный разлом проходит не только между социальными группами, но и в индивидуальном сознании. Каждый несет в себе неорганичность. Неоправданным упрощением является привычка моделировать реакции социальной общности исходя из предположения противостояния исключительно страт общества: представителей различных политических сил. Когда же налицо сочетание элементов до-, пост- и собственно индустриальных, неорганичность жизни возрастает.

Разумеется, усилия общества в переходный к новой общественной парадигме период сосредотачиваются как на создании научнообразовательно-производственных кластеров, так и на культивировании стимулирующей позитивные изменения общественной среды. Государство (в том числе и при поддержке местного самоуправления) берет на себя рутинно-повседневные (в частности, коммунальнобытовые) функции и задачи. Расширение задач государственного управления и социальной экономики - естественные направления в осовременивании социального государства. Представления об ответственном перед народом государстве общего процветания (благополучия) связываются с ценностно-смысловыми комплексами отнюдь не праздного безделья и/или потребительства, а созидания и творческого поиска. Между тем чем больше оснований у общества, чем более сложная внутренняя структура, тем она более устойчива в периоды относительных стабильности и изменений, тем более способна к дальнейшему развитию. Поэтому постглобальность как состояние культурно-цивилизационных миров включила в себя процессы децентрализации, регионализации и глобализация и стала естественным этапом организации безопасности и развития человечества. Полиструктура мирохозяйственных связей, основанная на выработанных и взаимоприемлемых нормативах отношений, а вовсе не 
блок из идентичных атомов-элементов, определяет вид постмодернистской действительности. При этом ни одна система ценностей не может рассматриваться как единственно прогрессивная для человечества, тем более насильно навязываться прочим.

Эта ситуация ориентирует отнюдь не на скопление разнообразных социальных иждивенцев и их обслуги, а на государственную поддержку разумной творческой активности (прежде всего духовноинтеллектуальной) с реализацией приоритета человека, его прав и свобод; социальной справедливости, то есть социального равенства людей в правах и возможностях; солидарности, понимаемой как выражение общности человечества и сочувствия к жертвам несправедливости. При этом адаптивность и эффективность общества предполагают как развёртывание собственных государственных форм и институций, так и своевременные их изменения соответственно появляющимся вызовам. Отличие инновационного народовластия от имитационного - в сохранении органичных для себя традиционных устоев, скрепляющих основания дальнейшего развития. Что, в свою очередь, востребует организации структур не полицейского государства (тем более в интересах внешних сил), а реального народовластия и, соответственно, ответственности за общественную жизнь. Соответственно, создание и развитие механизмов реализации народного суверенитета относятся к числу приоритетов структурирования общественной организации. Отстаивание своей самобытности - условие не только успеха, но и просто выживания. Напротив, формирование социально-политической культуры инфантилизма и иждивенчества, ожидание «манны небесной» ведёт к угодничеству перед сильными в данный момент и предательству интересов народа. Аппарат власти либо средство насилия и принуждения, либо направление делегирования и наделения полномочиями, создаётся на основании доверия вокруг базовых ценностно-смысловых комплексов или договора. Но вирусность чужеродных подходов в местной форме не только концентрируется в слое компрадорства/коллаборационизма, но и обостряет самозванство (в т. ч. олигархов), непосредственно или в конечном счёте вынужденное акцентировать силовой блок и формировать полицейское государство для паразитирования на народе. Собственно, ассоциирование индивидуального мастерства и кумулятивной синергетики среды и позволяет «сшивать» национальные особеннсти культурноцивилизационных миров с разнообразными достижениями. Поддержание же традиционных нравственных начал, обеспечение их инновационными формами имеет не только культурообразующее значение, но и играет государственнообразующую роль. 


\section{Выводы}

Обеспечение действенности и адаптивности общественного устройства вызывает необходимость быстрой реакции государства на возникающие исторические вызовы, в частности соответствующее изменение его структуры, органов, дебюрократизацию, законность, народность. Более гуманным, естественным и эффективным в широком понимании этого термина является развитие народовластия с государством социального типа. При этом избираемые культурноцивилизационными мирами виды и структуры как народовластия, так и государственности будут специфичны. Преодоление социальнополитических шаблонов само выступает фактором повышения качества социально-политической организации, в частности более высокого уровня поиска, культивирования и реализации творческой активности широких народных масс.

Вместе с тем дополнительная сложность расширения поля творчества и культивирования созидательной активности связана с разграничением разнокачественной инициативы. И локализация, и отсечение деструктивно-антисоциального агрессивного меньшинства - естественное условие органичного развития многостороннего творчества народа. В частности, требуется первоочередное рефлексивное восприятие и культивирование инициативы во внутренней политике, усиление давления международного сообщества на государства Запада в направлении обеспечения там прав и свобод населения, а также преодоления инерции колониализма и рабовладения - во внешней.

Таким образом, происходящие с государственностями в переходный период трансформации отнюдь не случайны, хоть далеко не все закономерности очевидны, для их выявления и существует наука, научная методология, интегрирующая абстрактно-логический и конкретно-исторический подходы. Её предназначение - обеспечить понимание процессов и осознанную общественную активность, в т. ч. исторического уровня и социетального масштаба. И как раз в переходный период некоторые критично важные закономерности проявляются и становятся отчётливо заметны. Достижение моральнонравственной, культурной, политико-идеологической зрелости критической массой людей - условие успешного перехода и использования «межевого времени». Тактические же организационноуправленческие формы зависят от конкретной ситуации. Соответственно, крайне важны: профессионализм и нравственность элит, отход от шаблонов «голого» администрирования, овладение новейшими техникой и технологиями, персональная ответственность за организационно-управленческие ошибки. В частности, на нормативноправовом уровне целесообразно зафиксировать для находившихся на финансировании из-за рубежа запрет на карьеру госчиновников или менеджеров в государственных корпорациях. Характер возникающей 
при переходе к новой общественной парадигме в единстве внутреннего устройства и мирового порядка сам по себе отнюдь не обрекает на хаос и бессмысленность, но требует концептуально-методологического знания и адекватности восприятия.

Таким образом, ныне государство занимает существенное место, в частности, в налаживании форм государственно-частного партнёрства при согласовании разнокачественных инициатив и творческих поисков. С одной стороны, независимость и безопасность развития вынуждают к преимущественной опоре на собственные силы. С другой стороны, отказ от унификации общественного устройства (в частности, государственности) упрощает повышения эффективности, гибкости и адаптивности при сохранении верности национальным устоям и традициям. Быстрый и продуманный ответ государства на появление исторических вызовов - часть реакции культурно-цивилизационного мира, обеспечивающей самосохранение и развитие. Соответственно, разрушение национальных государственностей - один из важных путей нанесения урона культурно-цивилизационным мирам. Двумя наиболее заметными тенденциями трансформаций государственного устройства и выступают усиление тоталитарно-корпоративистских характеристик либо черт народовластия; обезличивание ответственности - или её воплощение в конкретных лидерах. При этом, как известно, отбор и продвижение в корпоративном секторе не имеют ничего общего с народовластием. Да и процессы патологизации политико-экономической жизни могут и предполагать уход от прозрачного проведения всеобщих, прямых, тайных и равных выборов на высшие государственные должности, и включать широкие манипуляторные возможности медийной сферы.

Понимание необходимости баланса прав и обязанностей человека и гражданина имеет конкретно-исторический характер, завися как от стадии развития, так и от базовых ценностно-смысловых комплексов культурно-цивилизационных миров. Вместе с тем в противоборстве культурно-цивилизационных миров и слоёв порой сознательно применяют двойные стандарты при оценке событий и действий, искажая социальный простор проявлениями информационной войны соответственно своему пониманию интересов. При этом мощь, накопление и разброс оружия массового поражения увеличивают неподконтрольность разрушительных процессов. В этом контексте жонглирование вопросами как суверенитета и законности, так и прав и обязанностей может стать лишь разменной монетой на пути к гуманитарной катастрофе.

Повышение продуктивности последующего изучения темы, по нашему мнению, предполагает приоритетное изучение инструментария поддержания баланса между кооперацией и состязанием в формирующихся условиях. 


\section{Список использованных источников:}

1. Черникова И.В. Глобальный эволюционизм: философско-методологический анализ. Томск : Том. ун-т, 1987. 182 с.

2. Кобяков А.Б., Хазин М.Л. Закат империи доллара и конец «Рах Americana». Москва : Вече, 2003. 368 с.

3. Шедяков В.Е. Ритмы постсовременной модернизации: содержание и управление. Бизнес Информ. 1995. № 41-42. С. 6-9 ; № 43-44. С. 11-16 ; № 47-48. С. 52-54.

4. Шедяков В.С. Значення ритмів, хвиль та циклів оновлення та розвитку культурно-цивілізаційних світів у реалізації процесів соціогенезу. Нова парадигма. 2014. № 124. С. 53-70.

5. Шедяков В.Е. Социальное управление циклическими процессами трансформации общества: поиск оптимальности. Циклы природы и общества: тез. 3-й Междунар. конф. / под ред. В.Д. Чурсина, Ю.Н. Соколова, В.Е. Шедякова. Ставрополь, 1995. Вып. 1, 2. С. 284-286.

6. Соколова А. Проблема суверенитета и особенности политической трансформации государства в условиях глобализации. Москва : Власть, 2010. 345 с.

7. Малахов В. Государство в условиях глобализации. Москва : Проспект, 2016. $360 \mathrm{c}$.

8. Сергейцев Т., Куликов Д., Мостовой П. Идеология русской государственности. Континент Россия. Санкт-Петербург : Питер, 2020. 688 с.

9. Шедяков В.Е. Гармонизация индивидуального и социального в становлении общества знания. European vector of contemporary psychology, pedagogy and social sciences: the experience of Ukraine and the Republic of Poland / ed. board: M. Kiedrowska, A. Erechemla, T. Branecki. Sandomierz : Baltija Publishing, 2018. Vol. 3. P. 446-470.

10. Шедяков В.Е. Создание привлекательных условий жизни и благоприятных для творчества предпосылок - цель и условие долгосрочного эндогенного социальноэкономического развития при формировании «умного общества». The Development of International Competitiveness: State, Region, Enterprise: Proceed. of Intern. Scient. Conf. Lisbon, 2016. Part II. P. 34-36.

11. Шедяков В.Е Государственно-частное партнёрство в комплексе мер гармонизации экономических интересов в обществе. Економічний вісник Запорізької державної інженерної академії. 2017. Вип. 3(09). С. 7-14.

12. Бакунин М.А. Государственность и анархия. Москва : АСТ, 2021. 320 с.

13. Роль держави у довгостроковому економічному зростанні / ред. Б.С. Кваснюка. Київ ; Харків : Форт, 2003. 409 с.

14. Shedyakov V. Socially-oriented economy and social state as a need for organic development. New trends in the economic systems management in the context of modern global challenges / scient. ed. by M. Bezpartochnyi. Sofia : St. Grigorii Bogoslov, 2020. Vol. 2. P. 53-61.

15. Коротина Н.Ю. Оценка привлекательности государств на основе концепции «мягкой силы». АНТРО. Анналь научной теории развития общества. 2015. № 1. C. 71-81.

16. Shedyakov V. Pandemic and change of public paradigm: political and economic aspects of the transition. Pandemic Economic Crisis: Changes and New Challenges to Society / scient. ed. by M. Bezpartochnyi. Sofia : St. Grigorii Bogoslov, 2020. P. 48-60. DOI: https://doi.org/10.5281/zenodo.4396028 


\section{References:}

1. Chernikova I.V. (1987) Global'nyy evolyutsionizm: Filosofsko-metodologicheskiy analiz [Global Evolutionism: (Philosophical and Methodological Analysis)]. Tomsk: Izd-vo Tom. Un-ta. (in Russian)

2. Kobyakov A.B., Khazin M.L. (2003) Zakat imperii dollara i konets «Pax Americana» [The decline of the dollar empire and the end of «Pax Americana»]. Moscow: Veche. (in Russian)

3. Shedyakov V.E. (1995) Ritmy postsovremennoy modernizatsii: Soderzhanie i upravlenie [Rhythms of Postmodern Modernization: Content and Management]. Biznes Inform, no. 41-42, pp. 6-9; no. 43-44, pp. 11-16; no. 47-48, pp. 52-54. (in Russian)

4. Shedyakov V.E. (2014) Znachennja rytmiv, khvylj ta cykliv onovlennja ta rozvytku kuljturno-cyvilizacijnykh svitiv u realizaciji procesiv socioghenezu [The importance of rhythms, waves and cycles of renewal and development of cultural and civilizational worlds in the realization of the processes of sociogenesis]. Nova paradyghma, no. 124, pp. 53-70. (in Ukrainian)

5. Shedyakov V.E. (1995) Sotsial'noe upravlenie tsiklicheskimi protsessami transformatsii obshchestva: poisk optimal'nosti [Social management of cyclical processes of society transformation: search for optimality]. Tsikly prirody i obshchestva / Chursin V.D., Sokolov U.N., Shedyakov V.E. (eds.): Tez. 3 Mezhdunar. konf., vol. 1, 2. Stavropol', pp. 284-286. (in Russian)

6. Sokolova A. (2010) Problema suvereniteta i osobennosti politicheskoy transformatsii gosudarstva $v$ usloviyakh globalizatsii [The problem of sovereignty and features of the political transformation of the state in the context of globalization]. Moscow: Vlast'. (in Russian)

7. Malakhov V. (2016) Gosudarstvo v usloviyah globalizatsii [The state in the context of globalization]. Moscow: Prospekt. (in Russian)

8. Sergeytsev T., Kulikov D., Mostovoy P. (2020) Ideologiya russkoy gosudarstvennosti. Kontinent Rossiya [The ideology of Russian statehood. Continent Russia]. Sankt-Peterburg: Piter. (in Russian)

9. Shedyakov V.E. (2018) Garmonizatsiya individual'nogo i sotsial'nogo v stanovlenii obshchestva znaniya [Harmonization of the individual and the social in the formation of a knowledge society]. European vector of contemporary psychology, pedagogy and social sciences: the experience of Ukraine and the Republic of Poland / Kiedrowska M., Erechemla A., Branecki T. (eds.). Sandomierz: Baltija Publishing, vol. 3, pp. 446-470.

10. Shedyakov V.E. (2016) Sozdanie privlekatel'nyh uslovii zhizni i blagopriyatnyh dlya tvorchestva predposylok - tsel' i uslovie dolgosrochnogo endogennogo sotsial'noekonomicheskogo razvitiya pri formirovanii umnogo obshchestva [The making of attractive living conditions and favorable prerequisites for creativity is the goal and condition of long-term endogenous socio-economic development in the formation of an intelligent society]. The Development of International Competitiveness: State, Region, Enterprise: Proceed. of Intern. Scient. Conf. Lisbon, part II, pp. 34-36.

11. Shedyakov V.E. (2017) Gosudarstvenno-chastnoe partnerstvo v komplekse mer garmonizatsii ekonomicheskih interesov $\mathrm{v}$ obshchestve [State-private partnership in a complex of measures to harmonize economic interests in society]. Ekonomichnyj visnyk Zaporizjkoi derzhavnoi inzhenernoi akademii, vyp. 3(09), pp. 7-14.

12. Bakunin M.A. (2021) Gosudarstvennost' i anarkhiya. Moscow: AST. (in Russian)

13. Kvasnuk B.E. (ed.). (2003) Rolj derzhavy u dovghostrokovomu ekonomichnomu zrostanni [The role of the state in long-term economic growth]. Kyiv; Kharkiv: Fort. (in Ukrainian)

14. Shedyakov V. (2020) Socially-oriented economy and social state as a need for organic development. New trends in the economic systems management in the context of 
modern global challenges / Bezpartochnyi M. (scient. ed.). Sofia: St. Grigorii Bogoslov, vol. 2, pp. 53-61.

15. Korotina N.U. (2015) Otsenka privlekatel'nosti gosudarstv na osnove kontseptsii «myagkoy sily» [Appraisement of the attractiveness of states based on the concept of «soft power»]. ANTRO. Annaly nauchnoy teorii razvitiya obshchestva, no. 1, pp. 71-81. (in Russian)

16. Shedyakov V. (2020) Pandemic and change of public paradigm: political and economic aspects of the transition. Pandemic Economic Crisis: Changes and New Challenges to Society / Bezpartochnyi M. (scient. ed.). Sofia: St. Grigorii Bogoslov, pp. 48-60. DOI https://doi.org/10.5281/zenodo.4396028 